This is an Author's Accepted Manuscript of an article published in College \& Undergraduate Libraries, 18:150-169, 2011 [copyright Taylor \& Francis], available online at: http://www.tandfonline.com/10.1080/10691316.2011.577685

\title{
Other People's Money: Adapting Entrepreneurial Techniques to Build Capital in Challenging Economic Times
}

\author{
ROBERT FARRELL \\ Leonard Lief Library, Lehman College, CUNY, Bronx, New York, USA
}

\begin{abstract}
:
Drawing on the "predator" model of entrepreneurship put forward by Villette and Vuillermot in their 2009 book "From Predators to Icons," this article argues that challenging economic times reveal that self-funded, collaborative information literacy models have in many cases unsustainably overstretched staff and budgets. In such circumstances, it is necessary for librarians to shift to an entrepreneurial approach that seeks profitable opportunities funded by parties other than the library in order to build capital for current and future instructional services. Following Villette and Vuillermot, the article seeks to refute a cultural myth that sees the entrepreneur as someone who is first and foremost a "do-gooder" or marketer of helpful products, and it also advocates that librarians adopt a view of the entrepreneur as one who preys on unexploited, lowcost/ high-profit opportunities to leverage "other people's money" to build capital for later innovation. The article considers the economics of information literacy and library instruction programs, provides historical context for what has come to be known as the "collaborative imperative," points to the economic shortsightedness of many collaborative and "embedded librarian" partnerships, and details six examples from information literacy programs that model successful entrepreneurship of the sort argued for.
\end{abstract}

Keywords:

Collaboration, economic sustainability, entrepreneurship, information literacy, library instruction programs, strategic planning 
In line with the general goals of all information literacy (IL) programs, recent literature on college and university IL services has emphasized models of collaborative and embedded librarianship as ways of expanding instructional offerings and learning opportunities to as comprehensive a group of students as possible (Mounce 2010). A "collaborative imperative" has been recognized and responded to by college libraries due to a number of historical factors leading to a necessary increase in IL services. Iannuzzi's well-cited 1998 article, "Faculty Development and Information Literacy: Establishing Campus Partnerships," in which she promotes strategies for creating partnerships on college campuses that extend IL instruction into the disciplines and various other programs such as college writing centers, early college initiatives, etc., is characteristic of this push toward academic library collaboration. More recently, Shumaker et al.'s work to popularize the concept of embedded librarianship has become central to many models of IL instruction (2007, 2010). More and more libraries are dedicating more and more time to disciplinary instruction, often working with individual courses as much as the disciplinary faculty paid to teach those credit hours.

These approaches have helped move IL from the library into the curriculum. They reflect an admirable educational impulse. But they have also created a tension within libraries between the objective of increasing student learning opportunities and the financial and temporal realities that face our instructional programs, especially in challenging economic times. We have seemed to push aside the fact that current forms of innovative partnership rely on a high initial outlay of resources - what we might think of as capital, both financial and human - on the part of libraries, typically in the form of staff or faculty time and the transfer of resources from one service area to another.

In short, we haven't asked a simple question: How can we sustain our growing financial commitments to IL programs over the long term? How do we pay for it? In many respects, we've created a large number of unfunded mandates for ourselves, programs that during flush times are manageable but that become unsustainable when the economy falters, budgets shrink, and finite librarian work hours have to be stretched to cover noninstructional services. One thinks here of libraries that have had to lay off adjunct reference or instruction librarians or other contingent labor, shifting workloads and responsibilities to already maxed-out full-time staff. There will, of course, be those who believe that our IL mandates are not "unfunded" but are simply new responsibilities that should be paid for by increasing librarian "productivity," that is to say, by doing more in the same amount of time and for the same amount of money. To a point, this is true, and productivity can be improved. However, given the real increase in instructional workload and the very real complaints about the quantity of teaching in which librarians are engaged, it is a fact that many IL programs have become overstretched due to poor financial planning and the extension of instructional services without the resources needed to sustainably do so. 
Shumaker's column in Reference and User Services Quarterly touches on this fact, noting that the "resource effects" involved in developing and sustaining embedded librarian projects can be "substantial" $(2009,242)$. In challenging economic times, Shumaker's suggestions for mitigating resource effects - dropping activities to save money, requesting funds from administration, asking the customer to pay directly for embedded services they may have received for free, that is to say, on the library's dime — can be difficult if not impossible. What then are instruction programs and the librarians who manage them to do?

Drawing on the "predator" model of entrepreneurship put forward by Villette and Vuillermot in their 2009 book From Predators to Icons, this article will argue that challenging economic times require a shift to an interim entrepreneurial approach that seeks profitable opportunities funded by parties other than the library in order to build capital for future expenditure. While many librarians have attempted to adopt entrepreneurial approaches in the area of IL program development, they tend to see the entrepreneur as someone who is fundamentally an innovator, someone who looks for opportunities to introduce and expand needed or desired services in order, like Preston Tucker and his "car of the future," to benefit human kind (Tucker 2000). In short, we have bought into a myth that sees the entrepreneur as someone who is first and foremost a "do-gooder." From this standpoint, the entrepreneur is simply a marketer of sorts who gets people to want some great, good thing he's manufactured at his own expense.

Contrary to this myth, Villette and Vuillermot argue, entrepreneurs are not big risk takers willing to gamble their own resources for the sake of doing good in the world. Rather, they are risk averse and engage in what they call "predation." Entrepreneurs aim for the "sure thing," as Gladwell notes in his recent review of their book $(2010,24)$. They look for unexploited, low-cost/high-profit opportunities, and they find ways to use other people's money to build capital for their own later innovation. In libraries, new collaborative services should be thought of as innovations. Innovations, the authors argue, are "collective" endeavors that require partners. But more importantly, the authors remind us, collaborative work — innovation-is a "luxury you have to be able to afford" (Villette and Vuillermot, 84). The true entrepreneur knows that he first needs capital if he is to undertake new ventures or introduce new services.

Villette and Vuillermot's argument is simple: “one grows rich through innovating only on condition of having previously acquired the means of controlling the innovation and of being able to resist subsequent uncertainties," such as difficult economic times. "Mastery of innovation presupposes the control of sufficient financial resources and of a network of alliances enabling the distribution of expense and risk" (84). Translated into the world of academic libraries, Villette and Vuillermot's thesis tells us that libraries must adopt a truly entrepreneurial attitude if instructional services are to become 
more economically sustainable and if we are to weather recessionary periods.

We must look to build the needed capital and distribute financial risk

(both in the form of money and time) among partners outside the library

before introducing innovative collaborative services. And if we have already

over-extended ourselves, we must attempt to increase our capital to cover

current services and put ourselves in a position to continue growing our services

in more viable ways going forward. Again, innovation is a luxury you

have to be able to afford. For too long, libraries have ignored this fact and

they are now faced with cutting instructional services or asking already overburdened

librarians to teach more as others are pulled in different directions

or let go for budgetary reasons.

There are several historical and institutional reasons that have led us

to heed the collaborative imperative without heeding the need to prudently

build capital. I'll begin by considering these factors. I'll then clarify Villette and Vuillermot's portrait of the entrepreneur as predator and outline the steps of successful predation. In so doing, three projects recently undertaken in lieu of expanding existing collaborative relationships at Lehman College (City University of New York), projects that have avoided costs while maximizing "capital" accumulation, will be presented as examples of successful predation. Along with these projects, I will present several examples from other academic libraries. I'll conclude with a consideration of the social and psychological factors that may hinder librarians from adopting this needed predatory approach.

\section{WHY COLLABORATE? “THE COLLABORATIVE IMPERATIVE”}

To begin, let us state that the "collaborative imperative," the perceived need for librarians to work with faculty across disciplines to ensure that students are able to locate, evaluate, and use information intelligently, is a real imperative. I've adopted this phrase from the title of Raspa and Ward's The Collaborative Imperative: Librarians and Faculty Working Together in the Information Universe (2000) as much for its truth as for the sense of frantic urgency its title and much of its contents convey. As IL professionals, we know that our instruction is important if students are to succeed in the academic world as well as in the larger world outside the academy. Yet, what is it about this imperative that has led librarians to rush into collaborative relationships without first securing the necessary resources to do so? What has led us to initiate, in what retrospectively seems an almost headlong way, so many unfunded IL mandates? While the real needs of students have driven the growth of IL services, the haste in which it has been accomplished and the correlate lack of financial forethought can be seen as a result of a kind of felt "existential threat" to the profession as a whole and the need to make our services tangibly and immediately relevant. 
Between the late-1980s and mid-1990s, a variety of pressures began pushing librarians to rethink traditional models of bibliographic instruction. First, with the rise of new information technologies and the seeming ubiquity of information, teaching students how to utilize the physical spaces and resources of libraries through a single or small number of "one-shot" lessons no longer seemed adequate (Association of College and Research Libraries 1989). At the same time as this technological shift was occurring, college accreditors began emphasizing IL as a core learning objective across disciplines, introducing additional external pressures (Commission on Higher Education 1994; Ratteray 2002; Thompson 2002).

Third, following in the footsteps of John Dewey and other educational theorists, higher education in general began to shift to what has come to be called a "learner centered" model of instruction. Often cited as a seminal article in this area is Barr and Tagg's 1995 piece in Change, "From Teaching to Learning," in which the authors contrast the traditional "instruction paradigm" with what they called a "learner paradigm": college instruction that views the professor as an "inter-actor," someone who seeks to "elici[t] students' discovery and construction of knowledge" rather than simply someone who transfers his or her own knowledge to students (16). Shortly after the publication of Barr and Tagg's article, the influential report Reinventing Undergraduate Education, more commonly known as the Boyer Report (1998), was published. The report strongly advocated for a renewed attention to inquiry-based learning. While the Boyer Report only mentions libraries in passing, many librarians used the report and the general trend of the period as an opportunity to advance new inquiry-based initiatives requiring cross campus collaborations (Hensley 2006, 56-57; Thompson 2002; Watts 2008, 1).

Finally, after many years of cross-institutional conversation, the Association of College and Research Libraries issued its Information Literacy Competency Standards for Higher Education (2000), which set the bar for what students graduating from institutions of higher education ought to know and be able to do after completing their courses of study. Those accrediting agencies that hadn't yet issued formal guidelines for student IL performance did so shortly thereafter.

In response to these historical and institutional pressures, librarians began advocating for increased cooperation and collaboration across the disciplines and across the campus in order to give students the learning opportunities needed to meet these new perceived and mandated IL learning objectives. By 2000, Cook (2000) counted over four hundred articles published on the topic of librarian/disciplinary faculty collaborations and collaborations between various administrative and support service units and librarians. Iannuzzi's article was not the first to describe how to create successful, large-scale IL collaborations, but its emphasis on strategies aimed at influencing cultural changes favorable for IL initiatives in colleges and universities embodied a trend that seemed to reach a kind of critical mass 
at the time, while also exemplifying some of Rader's work from the period (1999). To this day, the topic remains important (Cochrane and Goodman 2009; Mackey and Jacobson 2005; Watts 2008).

These are real trends, and the pressures on libraries to supplement disciplinary instruction to help students become productive, independent inquirers have pushed librarians to expand IL services. However, an underlying fifth factor needs to be acknowledged. Unmentioned in the prevailing story of the rapid expansion of instructional services is the latent fear that new information technologies may in some way put librarians in the position of becoming obsolete, a fear that I believe has contributed to the haste and lack of financial forethought when it comes to IL program planning.

Two articles in the January 1996 issue of the Journal of Academic Librarianship seem to point to this worry. Wegner's brief op-ed, "Is it True What They Say?: The Library on a Credit Card," aims to refute a notion the author states in two concise sentences: "By the year 2000, books will be obsolete and the whole library will be accessible on a credit card! Library use will be entirely self-directed, with no librarian intervention necessary!" (51) Her conclusion is that libraries will continue to be needed because "librarianship ... is about making appropriate choices of resources and organizing that material into an intellectual whole. This requires space and persons. Because more and more, librarianship is about teaching, guiding, and interpreting" (52). Teaching students to be information literate is, in a sense, the thing that's going to keep librarians employed. Rider's article, "Developing New Roles for Paraprofessionals in Cataloging," is fascinating as a companion piece to Wegner's, for it seems to provide the historical context for the fears of reference and instruction librarians at the time. Rider's piece points to the ways automation and technological innovations led libraries to downsize or completely eliminate professional cataloging positions in favor of paraprofessional labor or altogether outsourcing cataloging activities. The trend Rider points to is one that began in the 1960s and has been discussed in the literature since then (Preston 1984).

Fears about librarian obsolescence are not unique to the mid-1990s, but a look at the literature does reveal those fears to be quite prevalent. Librarians continue to feel the pressure of justifying their jobs in the face of new technologies (Bivens-Tatum 2010; Huwe 2004). The rapid expansion of instructional services has, whether consciously or unconsciously, been one of the means to do so.

\section{ENTREPRENEURIAL ADVICE?}

As a result of these factors - the real needs of students, the pressures of accreditation and formalization of IL standards, and the real fear of what might happen if we did not justify our presence on college campuses-librarians were encouraged to adopt an "entrepreneurial" approach in order to expand 
IL services. Booth and Fabian (2002) advise librarians "to adopt a strategic, forward-looking, entrepreneurial approach for integrating the library agenda into institutional documents and for making IL a centerpiece of university success measures." (139) For them, the IL "entrepreneur" would seem to be someone capable of identifying unexploited markets and IL "needs" in order to thereby create new policies or services that give shape to those markets or fulfill those needs. Librarians in this scenario are encouraged to be creative "innovators," similar to those in the for-profit business world who identify new needs and demands and thereby invent products or services that bring profit to inventors and market innovators.

By "entrepreneurial," Booth and Fabian certainly do not mean the kind of external entrepreneurship advocated for by Neal in his 2001 article documenting the many "for-profit" business ventures established by the Johns Hopkins University Libraries. Rather, Booth and Fabian seem to equate entrepreneurship with a kind of marketing. In other words, they see entrepreneurship as an activity that seeks to promote and extend current services rather than an activity that is aimed at generating profits. This equation of entrepreneurship and marketing in the context of collaboration seems to be a common line of thought in academic librarian discourse (e.g., Bell 2009; Currie and Eodice 2005, 45).

In our efforts to respond quickly and comprehensively to the collaborative imperative, in our efforts to expand the scope of our instructional services, we've forgotten to ask how we intend to pay for these services, and, perhaps more importantly, how we will sustain and continue to grow them when budgets shrink. When it comes to finding the funds to pay for library services, ACRL (2006) advises that librarians frame to those holding the purse-strings how bad things will be and what various stakeholders will lose out on if funding is not provided for various services. The document does not address ways of developing programs that are profitable and self-sustaining. Its primary objective seems to be to make librarians into effective marketers of library services. However, this proves ineffective when campus budgets are cut across the board.

Academic libraries simply have not addressed the issue of funding IL services. A recent study of strategic IL planning in higher education analyzes documentation from a number of major universities for "key themes of information literacy strategy" (Corrall 2008, 31). While themes such as "Embed [IL] in curricula," "Work with others," and "Raise awareness [of IL services]" are readily identifiable, the author does not present evidence of strategic thinking in the area of resource acquisition. The financial costs of expanding IL services do not seem to be included in library planning and correlately have not been addressed in the literature.

Shumaker's (2009) suggestions for embedded library programs to cope with challenging economic times also belie an initial lack of strategic forethought. His advice to "charge-back" departments for already existing 
services is likely unfeasible for most academic libraries and to attempt to introduce it would perhaps even be politically damaging. Shumaker and Tyler note in 2007 that funding is a "challenge" for academic librarian embedded collaboration (7), and he points out that, unlike corporate or other special libraries, academic embedded services are not "funded by the customer" but rather "centrally managed and centrally funded" by the libraries themselves (21). His 2009 article's warning about "failing to allocate adequate funding and staff resources ..., inadequate attention to workload leveling . . , and overlooking the threats to library staff cohesion" (242), seems to be retrospective advice and leaves those planning future collaborative relationships with little practical guidance on avoiding the pitfalls of which he warns. In the absence of corporate-like funding models, academic librarians don't need to have the obvious consequences of overstretching library budgets and staff pointed out to them. We see this every day. Rather, we need strategic plans for figuring out how to fund embedded and collaborative relationships.

The first strategic step is to recognize that such collaborations may ultimately lead to deficits in difficult economic times. One must know that this is a possibility ahead of time, think about the collaborative relationship in terms of its long-range impact, and look for ways to carry the costs of those services that cannot be abandoned either for educational or political reasons. Too often collaborations are undertaken under the sway of immediate exigencies and for the sake of short-term "profits," such as meeting pressing accreditation demands, with little regard for their cost over the long run. The second step is for libraries to truly become entrepreneurial rather than simply creating more and more demand for their finite instructional supply, that is to say, librarian work hours. We must therefore have a clear conception of what characterizes entrepreneurial behavior. Entrepreneurship is not marketing. It is predation.

\section{PREDATORS VS. DO-GOODERS}

Villette and Vuillermot show that a myth has been built up around the notion of the "entrepreneur," blinding us to what entrepreneurs, or businessmen as the authors more prosaically choose to refer to them, really do. From the standpoint of the mythic conception of the entrepreneur, the "successfull businessm[a]n" is typically seen as "not only . . . a hero but as someone who sacrifices himself for the common good, at the risk of his life and fortune" (2). The word "entrepreneur," the authors point out, has connoted this myth among English speakers since it was first "introduced into economics by John Stuart Mill in 1848," who used it to refer to someone who "achieved something [or] accomplished a task": someone "through whom come prosperity and progress for the entire community" (19).

In other words, the myth is that the entrepreneur sees a need in society more clearly than others, sees the way to satisfy that social need, and then 
introduces innovative products or services, thereby transforming the world for the better. The entrepreneur is seen as a kind of noble "do-gooder," willing to risk his own capital or that of those who believe in his idea, for the sake of some social good.

For Villette and Vuillermot, the problem with this myth is that it has obscured how extremely successful business people, those who are known for their entrepreneurial spirit and for introducing socially beneficial innovations into the marketplace, positioned themselves to do so. Super-successful entrepreneurs start out not as heroes, but as risk-averse predators: ruthless business people whose sole aim is to accumulate as much capital as possible in the safest manner possible. Innovation only occurs after this phase of capital accumulation. This "successful businessman" is "constantly and almost exclusively on the lookout for opportunities to make profits higher than the cost of the capital he is using" (120). "In all stories of innovation," the author's write, "it is necessary to pay close attention to chronology: innovation occurs not at the beginning of prosperous business affairs but during them. Innovation follows other business deals that make it possible because they provide the outlet, the resources, and the funds. It is also because of these prior and preparatory business dealings that the businessman is able to grasp the full advantage of the inventions made by others, appreciate their potential value and, if possible, acquire them at low cost before that value has become known" (90).

By buying into the cultural myth of the entrepreneur, librarians have prioritized innovation and service growth while overlooking the need to first acquire the capital needed to implement such growth. Successful entrepreneurs may become "do-gooders" later in their lives or careers, but they usually don't start out as such. We must therefore rethink our conception of the entrepreneur if we are to regain our fiscal balance. The predator is someone who positions himself "'between' (entre) in order to 'take' (prendre)" (111).

\section{HOW THE PREDATOR PREYS}

Villette and Vuillermot follow many other theorists of entrepreneurship when they point out that successful entrepreneurs are typically those who have "made the most of unforeseen circumstances," (4), those who have "cleverly exploited exceptionally favorable business opportunities" (5). But the successful entrepreneur does not simply happen upon such opportunities, in their view. Rather, the "decisive operations" by which fortunes are made "chiefly ai[m] at recognizing, exploiting, creating or provoking market anomalies, momentary sources of large localized profits. In other words . . . [it is] essentially political work ..." (103).

The authors continue to say that the predaceous entrepreneur is always looking for undervalued commodities or businesses, things he can cheaply 
acquire and quickly turn over for the potential profit he perceives. He is looking for companies in distress that he believes he can acquire and turn around for his own gain. He is looking for deals in which he will be the stronger player in the position of reaping the most reward while risking the least out of those involved. As Villette and Vuillermot write, the skilled entrepreneur has an informed "view of the current and potential value of activities of which they have direct knowledge and which they have the means to influence." By "market anomalies" the authors mean inefficiencies in the marketplace: areas of the market in which things are either overor undervalued, the perception of which requires superior knowledge and insight.

In the following section, I will detail three IL ventures undertaken by the library for which I work. Each of these ventures required both aspects of successful predation outlined above: spotting a market anomaly ripe for exploitation and looking for ways to use other people's money, "capital" in the broad sense as we've defined it, to fund the venture. Three additional ventures from other libraries will serve to further illustrate the principles of predation Villette and Vuillermot describe.

To be clear, the "exploitation" here is not the kind of exploitation characteristic of the larger market place. No individuals unduly profited from these ventures in personal ways. Rather, the ventures yielded "profit" to the libraries in that they have positioned them to continue or expand these ventures or related ventures at little to no cost to the libraries. And if we wish to take this line of thinking farther, we can say that those who ultimately profited from these ventures are the students who received more extensive IL instruction than otherwise would have been available.

\section{SEEING WHAT'S THERE 1: PREYING ON AN EXISTING COURSE}

When first hired as the Coordinator of Information Literacy at Lehman College, the author examined the current course offerings throughout the various departments. Like all IL coordinators, the author found himself having to respond to the "collaborative imperative" and was looking for ways to extend our current IL reach, primarily through building relationships that would result in more course-embedded research sessions requested by disciplinary faculty. The author also came across an "introduction to college"-type course with a focus on online research listed under the Adult and Continuing Education Division. It had evidently been created many years prior by the division's Adult Degree Program, which offers a BA for nontraditional students returning to college. The course had ceased being offered.

Our library had never offered a for-credit IL course and we did not, at the time, seem to possess the kind of social capital needed to introduce such a course into the traditional BA program. However, it did seem feasible to 
set up a meeting with the Divisional Dean who oversaw the Adult Degree Program to discuss the possibility of the library reviving and reconceiving the course as a potentially useful class for new students to the program. When I approached the Chief Librarian, a position on our campus roughly equivalent to dean, with this idea, he suggested that the present moment might not be the best time to meet with the Divisional Dean. The Divisional Dean had been in his position for many decades and was due to retire in the coming year.

If we consider the two aspects that allow for successful predation, we can see that the library was positioned with an opportunity to do something that would be paid for by another campus entity. Since the course was offered through a department in a division separate from the library, whoever taught the course would be hired as an adjunct to teach the course at no cost to the library. In other words, here was an opportunity to undertake a venture, using someone else's money, which we would otherwise have thought of undertaking using our own money had circumstances and fiscal conditions allowed. Due to the Chief Librarian's insight into the current campus conditions, we also possessed information that allowed us to predict an impending anomaly in the "market." In our conversation, we recognized that the transition to the new dean would create an opportunity for us. That is to say, it would introduce a situation that we might be able to exploit rather than one requiring us to enter into a discussion with someone who had no incentive to innovate. Changes in corporate or institutional leadership often lead to shifts in corporate direction, shifts in strategy, and an openness to new ideas.

We therefore waited for the current dean to retire and approached the new dean with our proposal shortly after she received her appointment. Our strategy worked, and, with the guidance and input of the division and Adult Degree Program, we were able to retool the existing course on the books into something that would benefit the students of that department and give us a foot in the world of for-credit IL courses.

Consequently, the library gained a significant amount of profit, primarily in the form of social and political capital on campus. The success of creating a three-credit course that resulted in positive student outcomes has allowed us to be seen in a new light as an academic department capable of developing new curricula. We were able to see what was on the books and turn it into an opportunity.

\section{SEEING WHAT'S THERE 2: PREYING ON A STRUCTURAL ANOMALY}

LaGuardia Community College is a large urban institution located in Queens, New York, and is a part of the City University of New York. Over the past year, the library there was able to spot a structural anomaly in the course 
requirements for a number of majors and options (what most colleges would call "concentrations") that resulted from a change in the way science courses are offered at the college. By seeing what was already there, librarians created a two-credit course and obtained the funds to run the course; they are now in a position to guarantee student enrollment in their course while keeping their expenditure of human capital, in the form of work hours devoted to advertising the course, to a minimum. The librarians approached the campus Office of Institutional Research, which determined that over three thousand students were affected by the change. This became one of the main rationales by which they justified the creation of a new two-credit liberal arts IL course. Like other departments that create new courses, the library will receive a budgetary increase to pay for the instructor hired to teach the course. While the course constitutes a certain amount of "new work" for the library, it is work that is and will continue to be paid for by the college.

LaGuardia's library has long had a one-credit IL course. To sustain enrollment in that course, they developed strong ties with the college's advising department which has, over the years, funneled into that course students who need a single credit to fulfill a program requirement. They will continue to leverage that relationship in order to ensure enrollment in their new course without having to engage in extensive, time-consuming advertising to students and programs.

\section{OTHER PROGRAMS IN NEED 1: PREYING ON A GROWING DISCIPLINE}

As a member of the college's Academic Senate, the author first heard about a new program aimed at providing a crash course in business skills to liberal arts majors in need of practical training that was to be started using funds from a corporate grant. While semiautonomous, the program would be housed within and receive guidance from the college's business department.

A marketing-oriented instruction librarian would have approached the new program with an offer to provide course-based IL instruction or some sort of extracurricular workshops on business research. Neither of these was an option given our already large instructional program. While such offerings may have benefited students in some way, they would have eaten away at what little capital the library currently has by requiring us to invest library faculty time to schedule, plan, organize, and conduct workshops during hours already devoted to other vital tasks.

Rather than take this direction, the author used some of the social capital acquired through our successful (and profitable) collaboration with the Adult Degree Program by proposing to the coordinators of the new business 
program that the library create a course to support liberal arts students pursuing studies in business late in their college career. The coordinators of the program were intrigued by the idea, and the author drafted a mock course description and outline for a class on "competitive intelligence." After several more conversations with various stakeholders, we received an endorsement from the business department to develop a formal course proposal that could be sent to the college's Undergraduate Curriculum Committee. We subsequently did so and received a positive response from the chairperson of that committee who also suggested that the course be cross-listed with the business department itself, rather than offered solely under the aegis of the library, a very positive turn of events that we've since accomplished. By so doing, we believe we will more easily be able to attract students to the course since it will ultimately fit into the elective requirements for the Bachelor's of Business Administration degree rather than a course that has no degree impact, thus cutting down on any costs we may have incurred in time trying to get students to take the course.

Barring any unforeseen circumstances, by the time of this article's publication the course will have made its way through our College Curriculum Committee, and we foresee a positive outcome. Not surprisingly, however, we were initially met with a bit of confusion and skepticism by some of the stakeholders in the process. Since the library had never offered a course before, it took a few minutes for those hearing our proposal to realize that we are, in fact, a full academic department with librarians possessing full faculty status (something that helped us in this situation). It also helped that we could draw on the capital derived from the success of our recent collaboration with the Adult Degree Program to legitimate our venture.

Again, being aware of a change in the college's organization led us to see the initial anomaly we could use to our advantage. Monies for the course will have to be funded by the college budgeting process and will not come out of the library's existing personnel or other-than-personnel budget levels. A librarian will be hired to teach the course on an adjunct basis, which won't tap into existing funds. Just as in the previous case, it is the students who will be ultimate beneficiaries of this course. But we will also profit as well. On top of the additional social capital we hope to accrue for the purpose of continuing to develop new credit-bearing courses, there are other long-term benefits. We will profit down the road from our new relationship with the business department, a department that continues to grow, both in numbers of students and in importance to the college. Over the period of time spent developing the competitive intelligence course, the business department introduced a new graduate program. New changes to our institutional structure may give this department even more prominence than it currently has. What does that give us? With a three-credit business course in our department and additional library attention needed by the growing business department, we may be in a position to lobby for the creation of 
a business librarian position, someone who can teach the existing course as well as work to provide instruction within our other IL programs. This, in turn, will lessen the instructional load of current faculty, thus increasing the library's capital as understood in terms of faculty time able to be spent on various other projects.

\section{OTHER PROGRAMS IN NEED 2: PREYING ON A NEW MAJOR}

Immersion in the details of one's institution has been a common theme in the above examples. At the New York City College of Technology, a college also in the City University system, Information Literacy Librarian Maura Smale built political capital for her library by actively involving herself in campus committees and developing relationships, not solely for the purpose of developing collaborative relationships but also as a means of positioning herself to discover potentially exploitable opportunities. She did this in a number of ways.

When new to the campus, she volunteered to serve as a nonvoting member of her College Council's curriculum committee. Not only was she able to observe the process of new course initiatives from conception to approval, she got to know those serving on the committee in a more personal way, developing a set of personal relationships that could be tapped at some future point if opportunity arose. Second, her library, like most libraries, also has an active liaison program between librarians and academic departments that serves to facilitate collection development and identify departmental IL needs. Through the liaison program, she was able to get to know a variety of programs and the faculty teaching in those programs. Lastly, Maura became very involved in a variety of new technology initiatives, both on campus and within the larger university system, specifically by working on a new social media platform created by the university to facilitate intra- and intercampus communication and by participating in new cross-campus teaching with technology committees. This latter activity positioned her to develop vocabularies and conceptual frameworks by which to understand and communicate more effectively with the technologically-oriented programs with whom she worked in her capacity as a librarian within her college.

In this case, unlike the previous examples we've considered, Maura did not have to approach an entity outside her library with a proposal, but was rather approached by the creators of a new program in Emerging Media Technologies (offered through a department that she serves as liaison) about the possibility of creating a course for their department. To someone observing this event from outside the circumstances of its engendering, it would appear as if Maura were simply lucky to have been in the right place at the right time. By being known as someone familiar with the needs of new technological programs and as someone with the ability to navigate a new 
course proposal through the campus approval process, Maura was able to be perceived as someone to whom the Emerging Media Technologies program would naturally turn when the program discovered it needed a new course in research methods for its students. A profitable situation presented itself to her, seemingly by chance. However, her work building the social capital needed to attract the opportunity was acquired deliberately and thereby allowed the opportunity to arise and be effectively exploited.

Like the two-credit course at LaGuardia Community College and the competitive intelligence course at Lehman College, the course at City Tech has a built in base of students freeing the library from having to spend resources attracting students. Other departments that have seen the effectiveness of the course are now developing distribution models that include the library's research methods course as an elective option, thus allowing the library to expand the number of sections of the course going forward.

\section{OTHER PEOPLE'S MONEY 1: SPOTTING OPPORTUNITY IN A GRANT-FUNDED PROGRAM}

Grant writing can be quite labor intensive. It requires a large investment of time and energy that otherwise could be devoted to other projects. Additionally, grant applications are "risky." The odds of a library getting a major grant for an IL project are not high. Not only is there a lot of competition, there is also a lot of variation in funding levels and grant availability from various sources.

One way to minimize one's risk and correlatively maximize one's profit is to "piggy back" on grant applications written by other departments or college administrative units. To do this, one need only be networked with the active grant writers on campus and attuned to the conversations being had in various departments and among your campus grants coordinator or development officer.

Another way to minimize risk is to approach those you know who have recently received grants to see if they may need any services or programming that can be paid for out of their grant-funded coffers. If those who have received grants have worked with you before or know of the work you do and the services you provide, it is not unlikely that they will get in touch to see if you might be able to help them out.

As a result of previous traditional IL collaborations, our library was able to provide two four-day summer workshops for a group of junior high school students enrolled in an early college program run through a combined middle and high school associated with the college. And it did not cost the library a dime in time or money. Like our previous examples, these workshops were of a sort that at one point might have been done "on the clock" as part of 
a librarian's required duties, thus preventing that librarian from engaging in other activities and consequently impacting the library's productivity. Rather, we were able to have the program pay for our services through the other department's grant monies.

The author had previously provided instruction for this school's students who had enrolled in a college-level course and had the opportunity to get to know the program coordinator who is based on our campus. Over several months the author learned more about the early college program from her and was able to share with her some of the ideas that form the foundations of our IL program. She mentioned, in the course of our conversations, that she was in need of programming during the summer as part of her efforts to keep the junior high school students engaged and help them start thinking about the college-level courses they'd be taking in a few short years. The library was able to offer its services without hesitation, knowing that she would be able to fund any workshops we provided out of her own budget. Again, this saved the library from having to allot time and resources to an additional, unforeseen project. As an added bonus, a campus leader from the college's writing center was brought in to the project, which resulted in solidifying a budding partnership between her department and the library, a relationship that has since continued to bear fruit.

Like the previous examples, we relied on market knowledge to spot an anomaly ripe for "exploitation." If we had not come to know this program coordinator and been aware of her grant-funded project, or had not been attuned to her program's needs, this opportunity would have never been spotted. Knowing that there was a pool of operating money within the program allowed us to receive direct compensation for planning, as well as teaching, the workshops.

Again, those who profited most were the students who went through these workshops. But the library has accrued additional profits, both short and long term. As a result of undertaking this venture, the library and college writing center have developed new joint instructional programs. In addition, we recently presented some of our observations about the learning continuum we've seen between junior high and college students at a city-wide teacher librarian conference. The library has also now established a model of collaboration that requires partners to bring capital to the table in order to fund certain kinds of IL services.

\section{OTHER PEOPLE'S MONEY 2: SPOTTING OPPORTUNITY IN CAMPUS INCENTIVES}

In addition to grant-funded programs, opportunities to acquire money for library operations can be found by looking for various financial incentives 
tied to new campus initiatives. Our last example illustrates this technique and demonstrates that libraries can make "the most of unforeseen circumstances," to return to Villette and Vuillermot's phrase, to acquire monies that traditionally may be reserved for academic departments in the disciplines.

Like many institutions, the University of West Georgia (UWG), a school of about 11,500 undergraduate and graduate students, is feeling pressure to move more of its instruction into an online environment. It is a priority at the university as evidenced by the peer-reviewed journal, The Online Journal of Distance Learning Administration, published on campus. Anne Barnhart, Head of Instructional Services at the UWG library, and her colleagues discovered that their institution offers departments extra financial incentives to offer online courses. Students within their system pay a unique "etuition" rate for online courses, the proceeds of which are split among the distance education program, which receives 40 percent of each enrolled student's tuition, the department, which also receives 40 percent, and the administrative unit of the college, which receives the remaining 20 percent. Because the library is itself an administrative unit and a department, they are able to directly receive 60 percent of every student's tuition, 20 percent more than other departments, money that is designated by the university to enhance online teaching, learning, or other services. The money has been used to purchase hardware, including iPads used for online instruction, and their Libguides subscription.

In 2010, the library discovered that an additional incentive could be obtained by creating more advanced courses for students in the university's "honors" track. A department receives an additional \$2500 for each honors course that it offers; these funds can be used for any purpose. The library offered its first section of an honor's IL course in the fall 2010 semester, and it was able to use the funds to increase their travel budget and purchase supplies needed to extend their outreach and promotional activities on campus, producing brochures and customized pens, in order to attract more students to their courses. They now hope to offer an honor's section each year, both in order to exploit the funds being offered and as a way to work with more advanced students and thereby develop their IL curriculum in new directions.

\section{BECOMING A SUCCESSFUL PREDATOR}

Librarians are not typically thought of as predators. But if we are to avoid continually collaborating in ways that overstretch our resources, we need to become so. It may be the case that we have seen less of this sort of approach in the nonprofit or academic world, primarily because these sorts of careers don't attract this kind of personality type. Those who are "other directed" or who gravitate to the security and sense of purpose that comes 
from being a part of a large, socially minded institution may not possess by nature the predator instinct needed to build capital and advance the positive educational agenda they value. Librarians are helpful, giving people. When there is a need or problem, we are trained to recognize it. Our instinct is to quickly try to satisfy or solve it. We want to supply the services that will give our "customers" the skills we know will serve them well. We want to expand our services through cross-disciplinary partnerships as quickly and as widely as we can. But we must do so in a calculated way, not hastily due to fears of becoming obsolete or looming accreditation requirements or the need to prove our own worth.

The ability to introduce new "products," develop new methods of service delivery, and integrate services into new markets requires the kind of capital, whether economic or social, needed to "fund" such ventures if those ventures aren't to bankrupt us or leave us without the capital needed to sustain other core services and operations. Researchers in the area of social entrepreneurship are beginning to look seriously at the issue of "profitability" and capital accumulation in order to give leaders in those fields new ways to think about the long-term viability of their services. We must do so, too.

As Villette and Vuillermot note, the successful business person "pursues his egotistical interests, adopts risky behavior, and speculates on uncertainty" in order to achieve his end of maximizing profits needed to fund current and future ventures (21). If we substitute the words "the students" or "his patrons" for "his egotistical," the above sentence sounds much more in line with our own values, for the personal interests of dedicated librarians truly are the same as those about whose educations we care. What is important to note in Villette and Vuillermot's observation is that it is necessary to operate in what we might call a moral "gray zone" if we are to advance our agenda and respond to the collaborative imperative in a sustainable and profitable way. "The entire difficulty," for the predatory entrepreneur, they conclude, "consists in combining the rapid accumulation of economic capital with the accumulation of symbolic capital - a good reputation in business" (110). But success begets success and positive results very often are remembered while the means by which they were attained forgotten. As Villette and Vuillermot point out, "The authority acquired by successfully accomplishing operation A can be reinvested in the form of a promise of success in a future operation B. A snowball effect can therefore be observed, success leading to a sort of symbolic credit facilitating the next success" (4).

While approaching collaborative innovation in the Machiavellian way described here may be distasteful to some, the capital that one can accrue by such methods is not acquired for the glory of one's IL program. It is accumulated in order to make our colleagues and ourselves less harried and overstretched. It is accumulated to give us more time to reflect, plan, and prepare. And, it is ultimately for our students who will profit from our renewed and sustained attention. The capital acquired by the predatory 
developer of IL programs is the source from which future opportunities

for student success will be funded. In this way, growth through innovative collaborative partnerships becomes truly sustainable.

\section{REFERENCES}

Association of College and Research Libraries, American Library Association. 1989. Presidential committee on information literacy: Final report. http://www.ala.org/ala/mgrps/divs/acrl/publications/whitepapers/presidential.cfm. . 2000. Information literacy competency standards for higher education. http://www.ala.org/ala/mgrps/divs/acrl/standards/standards.pdf.

- 2006. The power of personal persuasion: Advancing the academic library agenda from the front lines. http://www.ala.org/ala/mgrps/divs/acrl/issues/marketing/advocacy toolkit.pdf.

Barr, R. B., and J. Tagg. 1995. From teaching to learning - a new paradigm for undergraduate education. Change 27:12-25.

Bell, S. J. 2009. The librarian entrepreneur? Demystifying an oxymoron. Against the Grain 21:18-20.

Bivens-Tatum, W. 2010. The lesson of library history. Academic Librarian: On Libraries, Rhetoric, Poetry, History, \&Moral Philosophy, February 15. https://blogs. princeton.edu/librarian/2010/02/lesson of library history.html.

Booth, A., and C. A. Fabian. 2002. Collaborating to advance curriculum-based information literacy initiatives. Journal of Library Administration 36:123-42.

Boyer Commission on Educating Undergraduates in the Research University. 1998. Reinventing undergraduate education: A blueprint for America's research universities . Stony Brook: State University of New York at Stony Brook. http://naples.cc.sunysb.edu/Pres/boyer.nsf/.

Cochrane, L. S., and V. D. Goodman, eds. 2009. Agility by design: Library collaborations across and beyond the campus. Special Issue, College \& Undergraduate Libraries 16, nos. 2-3.

Commission on Higher Education, Middle States Association of Colleges and Schools. 1994. Characteristics of excellence in higher education: Standards for accreditation . Philadelphia: Commission on Higher Education, Middle States Association of Colleges and Schools.

Cook, D. 2000. Creating connections: A review of the literature. In The Collaborative imperative: Librarians and faculty working together in the information universe , ed. R. Raspa and D. Ward, 19-38. Chicago: Association of College and Research Libraries.

Corrall, S. 2008. Information literacy strategy development in higher education: An exploratory study. International Journal of Information Management 28:26-37.

Currie, L., and M. Eodice. 2005. Roots entwined: Growing a sustainable collaboration. In Centers for learning: Writing centers and libraries in collaboration, ed. J. K. Elmborg and S. Hook, 42-60. Chicago: Association of College and Research Libraries. 
Gladwell, M. 2010. The sure thing: The myth of the daredevil entrepreneur. New Yorker , January 18, 24-29.

Hensley, R. B. 2006. Ways of thinking: Doing research and being information literate. In Student engagement and information literacy, ed. C. Gibson, 55-67. Chicago: Association of College and Research Libraries, American Library Association.

Huwe, T. K. 2004. Building digital libraries: Being organic gives reference librarians the edge over computers. Computers in Libraries 24:39-41.

Iannuzzi, P. 1998. Faculty development and information literacy: Establishing campus partnerships. Reference Services Review 26:97-102, 116.

Mackey, T. P., and T. E. Jacobson. 2005. Information literacy: A collaborative endeavor. College Teaching 53:140-44.

Mounce, M. 2010. Working together: Academic librarians and faculty collaborating to improve students' information literacy skills: A literature review 2000-2009. The Reference Librarian 51:300-20.

Neal, J. G. 2001. The entrepreneurial imperative advancing from incremental to radical change in the academic library. Portal: Libraries and the Academy 1:1-13.

Preston, G. 1984. How will automation affect cataloging staff? Technical Services Quarterly 1:129-36.

Rader, H. B. 1999. Faculty-librarian collaboration in building the curriculum for the millennium: The U.S. experience. IFLA Journal 25:209-13.

Raspa, R., and D. Ward. 2000. The collaborative imperative: Librarians and faculty working together in the information universe . Chicago: Association of College and Research Libraries.

Ratteray, O. M. T. 2002. Information literacy in self-study and accreditation. The Journal of Academic Librarianship 28:368-75.

Rider, M. M. 1996. Developing new roles for paraprofessionals in cataloging. Journal of Academic Librarianship 22:26-32.

Shumaker, D. 2009. Who let the librarians out?: Embedded librarianship and the library manager. Reference \& User Services Quarterly 48:239-42.

Shumaker, D., and M. Talley. 2010. Models of embedded librarianship: A research summary. Information Outlook 14:26-35.

Shumaker, D., and L. A. Tyler. 2007. Embedded library services: An initial inquiry into practices for their development, management, and delivery. Paper presented at the Special Libraries Association Annual Conference, Denver, CO.

http://www.sla.org/pdfs/sla2007/ShumakerEmbedddedLibSvcs.pdf.

Thompson, G. B. 2002. Information literacy accreditation mandates: What they mean for faculty and librarians. Library Trends 51:218-41.

Tucker: The man and his dream . 2000. DVD. Directed by Francis Ford Coppola. Hollywood: Paramount.

Villette, M., and C. Vuillermot. 2009. From predators to icons: Exposing the myth of the business hero . Ithaca, NY: ILR Press.

Watts, M. W., ed. 2008. Information literacy: One key to education. Special issue, New Directions for Teaching and Learning, no. 114.

Wegner, L. S. 1996. Is it true what they say?: The library on a credit card. Journal of Academic Librarianship 22:51-52. 